\title{
茶園に㧍けるジシアンジアミド入り被覆尿素の施用効果
}

\author{
鹿児島県農業開発総合センター茶業部*1 \\ 三浦伸之・内村浩二*2 ·加治俊幸*3.中村孝久*4. \\ 吉田真 - *5 ·勝田雅人・鳥山光昭 \\ (平成18年12月 4 日受理)
}

\section{Effects of Application Using Coated Urea and Dicyandiamide for Tea Field}

\author{
Nobuyuki Miura, Koji Uchimura, \\ Toshiyuki Kaji, Takahisa Nakamura, \\ Shinichi Yoshida, Masato Katsuda \\ and Mitsuaki Karasuyama \\ Tea Division, Kagoshima Prefectural Institute for Agricultural Development
}

\section{Summary}

In order to ascertain the effects of the inhibition of long-range nitrification in tea field soils, we examined the application method using coated urea and dicyandiamide (nitrification inhibitor, Dd). Our findings are described in the following.

The nitrogen release of the 70-day type of coated urea and $\mathrm{Dd}$ was more specifically late in early spring than was the conventional 70-day type of coated urea. On the other hand, the nitrogen release of the 40-day type of coated urea and Dd was similar the conventional 70-day type of coated urea in regard to early spring. These results show the advantage of applying the 40-day type of coated urea and Dd in the spring compared with the conventional 70-day type of coated urea.

We next compared the conventional coated urea and the coated urea and Dd when applied in a tea field in the fall, spring, and summer. Higher rates of ammonium nitrogen were found in mineral nitrogen following the application of the coated urea and Dd than following the application of the conventional coated urea. This result demonstrates the nitrification inhibition by Dd. The application of coated urea and Dd led to a rise in the recovery rate of fertilization

*1 旧 鹿児島県茶業試験場 テ897-0303 鹿先島県川辺郡知覧町永里3964

*2 現 鹿児島県農業開発総合センター企画調整部 个899-3401 鹿児島県南さつま市金峰町大野2200

*3 現 鹿悲島県農業開発総合センタ一德之島支場 テ891-8114 鹿览島県大島郡伊仙町面縄2092

*4 現 鹿児島県南薩地域振興局農林水産部農政普及課 ₹897-1121 鹿巟島県南さつま市加世田唐仁原1954-3

*5 現 鹿恣鳥県北薩地域振興局農林水産部出水支所農政普及課 T 899-0202 鹿児島県出水市昭和町18-18 
nitrogen by the tea plants, while the quality of the 2nd and 3rd tea crops improved. Moreover, the concentration of nitrogen leaching from the application of the coated urea and Dd was reduced compared to the application of the conventional coated urea.

However, 3-4 years later, the concentration of nitrogen leaching from the application of the coated urea and Dd was not reduced. Analysis of the tea field soils showed more available nitrogen following the application of the coated urea and Dd than following the application of the conventional coated urea, and even with the addition of Dd to the soil solutions, the ammoniumoxidizing bacteria following the application of the coated urea and Dd did not decrease. These results suggest that when the coated urea and Dd was applied continuously, the concentration of nitrogen leaching did not reduce. This was due to 1) the increase of nitrogen leaching derived from the accumulating available nitrogen, and 2) the suppression of the decrease of ammoniumoxidizing bacteria.

Key words: coated urea and dicyandiamide, leaching of nitrogen, nitrification inhibitor, tea field, uptake of nitrogen

\section{1 緒 言}

日本の緑茶は旨味を重要視するため，アミ ノ酸等の窒素含量が多いほど高品質とされ， 茶園では年間窒素施用量 $100 \mathrm{~kg} / 10 \mathrm{a}$ 超える 多量の肥料が施用されてさた ${ }^{1}$ 。しかし, 1999 年 2 月に硝酸態窒素及び亜硝酸態公素が, 国 の定める”河川および地下水の水質污濁に係 る環境基準”に設定され, 施肥による茶園周辺 の地下水への窒素負荷が懸念されたことから， 窒素施肥量の低減对策が緊急課題となった。

茶園における效率的な施肥技術の一つとし て, 硝酸化成抑制剂 (以下, 硝化抑制剂) の 利用 ${ }^{2 \sim 4)}$ が提唱されている。硝化抑制剂の 内, ジシアンジアミド（以下，Dd）を添加 した効果について, 西野 ${ }^{5)}$ は, 二番茶の品 質向上が認められ，窒素溶脱量は溶出の緩や かなCDU化成やIB化成と同等であったが， 被覆燐硝安加里より多かったと報告してい る。また, 加藤ら ${ }^{6)}$ は, Ddが土壤中に保持 される期間が 1 ケ月程度と短いことを報告し ている。Ddを土壤中に長期間維持すること ができれば，持続的な効果が期待できること から，2000年，チッソ旭肥料株式会社は,
Dd入り被覆尿素（DdLPコート）を開発した。 この資材は，尿素にDdをコーティングし， 更に被膜をコーティングしたものである。

そこで本報では，このDd入り被覆尿素の 茶園における効果を, 窒素施用量を同量とし たDdコーティングのない被覆尿素（以下， 被覆尿素）との比較により検討した。

\section{2 方法}

2. 1 各施肥時期における $\mathrm{Dd}$ 入り被覆尿 素の空素溶出特性

市販の不織布袋（お茶パック）に，被覆尿 素40日タイプ（LPコート40, 窒素42\%) 及 び被覆尿素70日タイプ（LPコート70, 絰素 $42 \%), D d 入 り$ 被覆尿素40日タイプ（DdLP コート 40，窒素42\%，うちDd態窒素4.2\%), Dd入り被覆尿素70日タイプ(DdLPコート70,

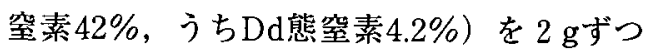
入れ，それらを市販のメッシュ袋（水切りネ ット）に重ならないように並べた。2002年 9 月 12 日及び 2003 年 2 月 5 日， 4 月 30 日， 8 月 20 日，2004年 2 月 13 日，5月 1 日に鹿览島県 茶業試験場内の厚層多腐植質黑ボク土茶園の うね間深さ $5 \mathrm{~cm}$ 位置に敷き，軽く覆土した。 
ただし，2002年 9 月12日は被覆尿素40日タイ プでなく, 被覆尿素50日タイプ (LPコート 50，窒素42\%）を用いた。その後，93〜140 日後まで適宜回収し, 硫酸分解法 ${ }^{7}$ により 各被覆尿素内の全窒素量を分析した。各被覆 尿素の全窒素量の減少量から窒素溶出率を算 出した。試験は 3 反復で行った。

\section{2. $2 \mathrm{Dd}$ 入り被覆尿素の収量及び品質, 土壤への影響}

場内の厚層多腐植質黒ボク土, ‘やぶきた’ 樹齢約30年の成木園において，2001年 8 月〜 2004年 5 月の中切り更新処理まで試験を行っ た。表 1 に窒素施用量を示す。対照区は, 秋 肥, 夏肥, 春肥として被覆尿素入り有機質配 合肥料（窒素成分の約50\%はLPコート70）, 芽出し肥として硫安を組み合わせ, 年間窒素 施用量を $50 \mathrm{~kg} / 10 \mathrm{a}$ とした。一方，Dd区は， 対照区の資材に含まれるLPコート70をDdLP コート70（3 年目の春肥はDdLPコート40） に替えて，その他の資材及び窒素施用量は全 て対照区と同様にした。なお，堆肥は両区と も無施用とした。両試験区は 1 区 $21.6 \mathrm{~m}^{2}$ $(12 \mathrm{~m} \times 1.8 \mathrm{~m})$ の 3 反復で, 摘採は乗用型摘 採機で行った。荒茶加工は 3 反復分を 1 点に まとめ, $2 \mathrm{~kg}$ 少量製茶機で行った。但し, 試験 3 年目は一番茶後中切り更新をしたた め, 2.3 試験ほ場（後述）の二番茶を荒茶 加工して，供試した。また，うね間土䗙は， 両区直径 $35 \mathrm{~mm}$ の採土器を用いて, 定期的に $0 \sim 20 \mathrm{~cm}$ 及び20〜 40cmの層位を 2 カ所ずつ
採取し，よく混合した。この土㙵を風乾せず に $2 \mathrm{~mm}$ の筛で節い，無機態窒素をブレムナ 一法 ${ }^{8)}$ で測定した。なお，2004年 4 月28日 に採取したうね間土壤からは, 細根を採取し， その乾物量を測定した。

荒茶の官能審查は, 形状, 色沢, 香気, 水色, 滋味を各20点満点の標準審查法で, 全窒素及 び遊離アミノ酸，NDF（中性デタージェン 卜繊維）の分析は近赤外分析計 (DICKEYjohn社製）及び静岡製機(秼の煎茶用検量線を 用いて行った。

\section{3 Dd入り被覆尿素の窒素溶脱への影響} 場内の多腐植質黑ボク土, ‘やぶきた’ 樹 齢14年のライシメーター園 $\left(3.6 \mathrm{~m}^{2}\right.$, 深さ 1 m) において，2001年 8 月〜2005年 9 月まで 試験した。2．20試験と同様に対照区及び $\operatorname{Dd}$ 区を設置し， 3 反復とした。摘採は水平 仕立て用 (曲率半径 $3000 \mathrm{~mm}$ ) の可搬型摘採

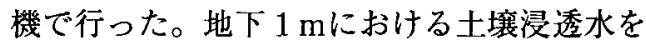
採取し，硝酸態窒素をイオンクロマトグラフ イーにより測定した。また，うね間土壤の採 取は2005年 8 月 15 日に $0 \sim 20 \mathrm{~cm}$ 層位を 2 . 2 と同様に行い, 土壤分析 ${ }^{8)}$ を, $\mathrm{pH}$ はガラ 又電極法, 全窒素は硫酸分解法, 可給㦔窒素 は中性リン酸緩衝液抽出法, 無機態洷素はブ レムナー法で測定した。

\subsection{Dd入り被覆尿素の連用土壌におけ るアンモニア酸化細菌のDd感受性} 2005年 9 月26日に採取した 2.3 の試験の

表 1 窒素施用量 $(\mathrm{kg} / 10 \mathrm{a})$

\begin{tabular}{cccccc}
\hline 区 名 & $\begin{array}{c}\text { 秋肥 } \\
(8 \sim 9 \text { 月 })\end{array}$ & $\begin{array}{c}\text { 春肥 } \\
(2 \text { 月 })\end{array}$ & $\begin{array}{c}\text { 芽出し肥 } \\
(3 \text { 月 })\end{array}$ & $\begin{array}{c}\text { 夏肥 } \\
(\text { 一番茶摘採後 })\end{array}$ & 年間 \\
\hline 対照区 & $10.0^{\mathrm{a}}$ & $20.0^{\mathrm{a}}$ & $7.8^{\mathrm{c}}$ & $12.2^{\mathrm{a}}$ & 50.0 \\
Dd区 & $10.0^{\mathrm{b}}$ & $20.0^{\mathrm{b}}$ & $7.8^{\mathrm{c}}$ & $122^{\mathrm{b}}$ & 50.0 \\
\hline
\end{tabular}

注） a ：LP70入り有機質配合肥料， b:DdLP70入り有機質配合肥料 (但し， 3 年目春肥はDdLP40入り), $\mathrm{c}$ ：硫安 
対照区及びDd区のうね間土壌を供試した。 最確值法 ${ }^{8)}$ に準じ，試験管を用い，5 反復 で10〜10 ${ }^{6}$ 倍に希釈した。土壤希釈液 $1 \mathrm{~mL}+$ アンモニア酸化細菌用培地 ${ }^{8)} 3 \mathrm{~mL}$ に対して, $0.11 \mathrm{mg}$ のDd（一次希釈で夏肥の約 5 倍量換 算）を添加し，Dd無添加の試験管とともに， $28^{\circ} \mathrm{C}$ で 2 週間保温静置してアンモニア酸化細 菌数を計测した。

\section{3 結果}

3. 1 各施肥時期におけるDd入り被覆尿 素の窒素溶出特性

図 1 に各施用時期における各被覆尿素から
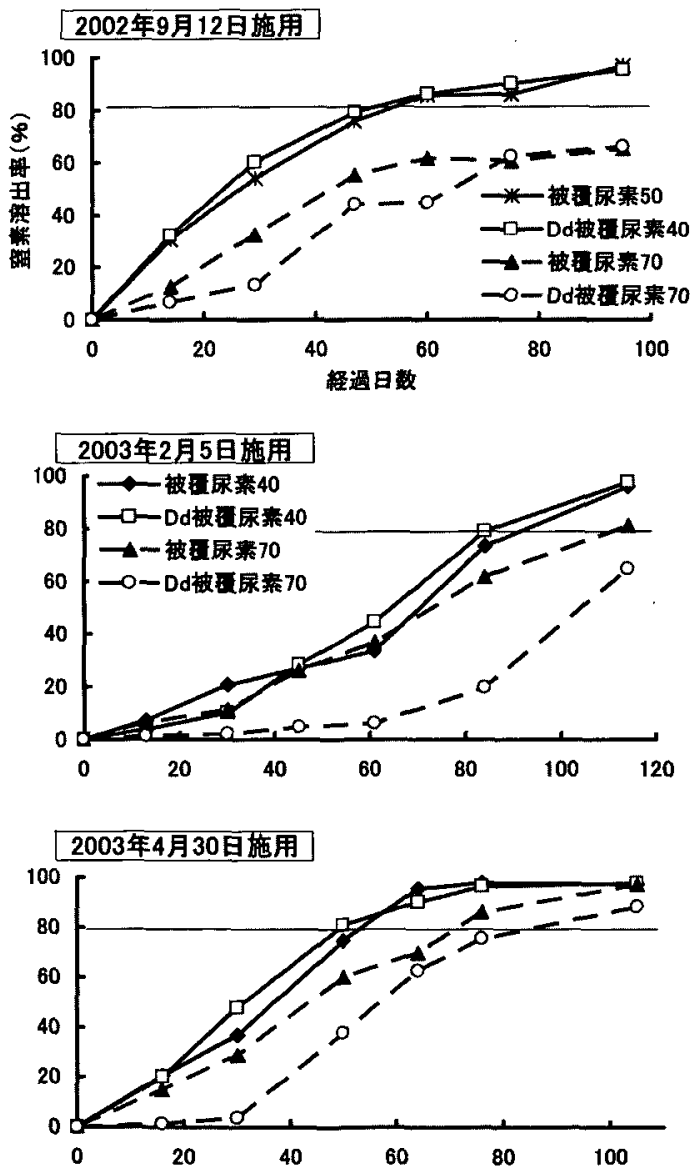

の紸素溶出を示す。各被覆尿素の窒素溶出パ ターンは，2002年 9 月 12 日及び2003年 8 月 20 日の施用では比較的りニア型に近似していた が，2003年 2 月 5 日及び2004年 2 月 13 日の施 用ではスーパーシグモイド型，2003年 4 月 30 日及び2004年 5 月 1 日の施用ではシグモイド 型に近似していた。Dd入り被覆尿素40日タ イプの窒素溶出は，2002年 9 月12日施用では 被覆尿素50日タイプと，2003年 4 月30日及び 2003年 8 月20日施用では同40日タイプと近似 していたが，他の施用時期では，同40日タイ プに比べて，初期の溶出率が低く，施用60日 後までは同70日タイブと近似していた。一方，
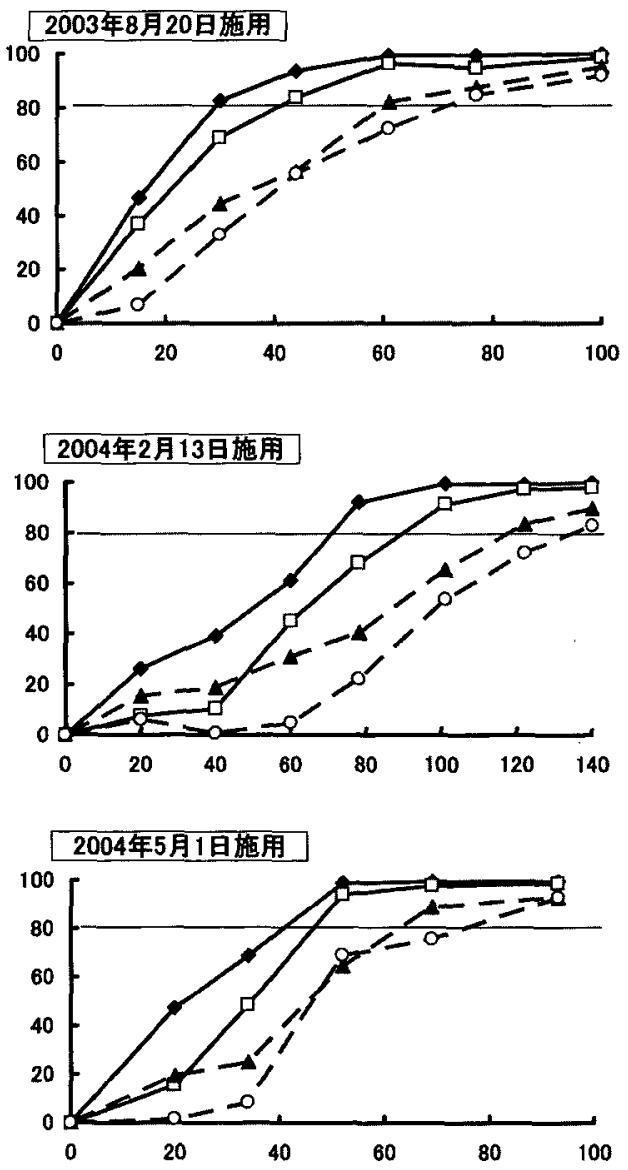

図1各施用時期における各被㻼尿素からの窒秦溶出 
$\operatorname{Dd}$ 入り被覆尿素70日タイプの窒素溶出は, 被覆尿素70日タイプに比べて，どの施用時期 におらいても初期の溶出率が低く，特に，2003 年 2 月 5 日及び2004年 2 月 13 日施用における 施用60日後の溶出率は10\%以下と著しく低か った。

3. $2 \operatorname{Dd}$ 入り被覆尿素の収量及び品質, 土壤への影響

図 2 に生葉収量を示す。Dd区の生葉収量 は, 3 年間の各茶期を通じて, 対照区と同等 の収量であった。

表 2 に対照区に対するDd区の荒茶官能審 查の評点差を示す。Dd区の荒茶品質は，対
照区に比べて， 1 年目一番茶の滋味及び 1 年 目二，三番茶の内質全般， 2 年目三番茶の内 質全般， 3 年目の二番茶水色で優れた。 2 年 目一番茶は香気及び滋味で劣ったが，これは Dd区に移り香による異臭が微かに認められ たことが影響したと考えられた。総じて， Dd区は二，三番茶の内質が優れる傾向が認 められた。

表 3 に荒茶の化学成分を示す。Dd区の全 窒素及び遊離アミノ酸含有率は, 対照区に比 べて， 1 年目一番茶及び 2 年目三番茶以外の 各茶期で高かった。また，Dd区のNDF含有 率は, 1 年目二番茶で対照区より低かったが, 他の時期は同等であった。

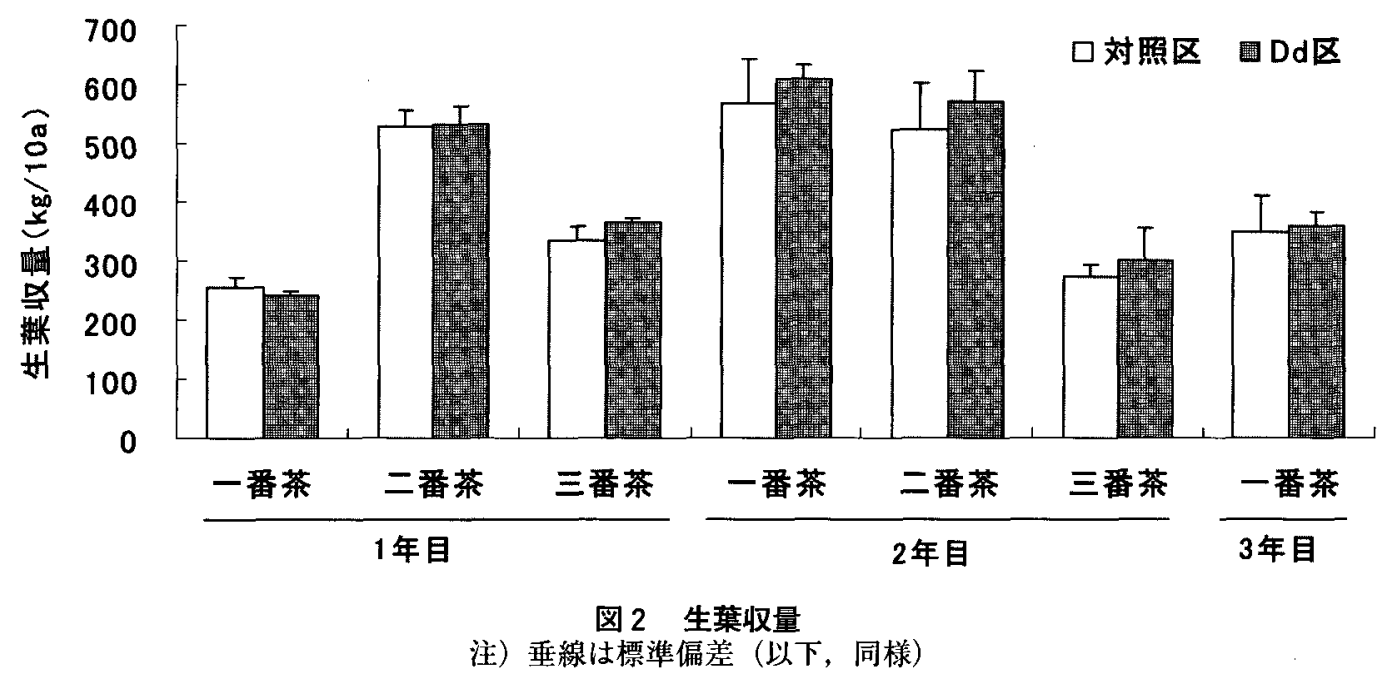

表 2 対照区に対するDd区の荒茶官能審査の評点差

\begin{tabular}{|c|c|c|c|c|c|c|c|}
\hline & 茶期 & 形状 & 色沢 & 香気 & 水色 & 滋味 & 合計差 \\
\hline \multirow[t]{3}{*}{1 年目 } & 一番茶 & (O) & - & - & - & (2) & 1.0 \\
\hline & 二番茶 & - & - & (a) & (2) & (0) & 3.0 \\
\hline & 三蕃茶 & - & - & (a) & (2) & (0) & 4.5 \\
\hline \multirow[t]{3}{*}{2 年自 } & 二蕃采 & 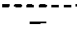 & - & A & - & A & -2.7 \\
\hline & 二番茶 & - & - & - & - & - & 2.7 \\
\hline & 三番茶 & - & - & (a) & (a) & (a) & 4.5 \\
\hline \multirow{2}{*}{ 3年自 } & 二蕃茶- & 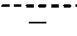 & - & 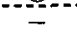 & 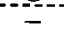 & - & -2.0 \\
\hline & 二番茶 $*$ & - & - & - & (D) & - & 2.5 \\
\hline
\end{tabular}

注 1）各20点満点の標準審查法, 対照区との差が 1 点以上は@，-1点以下はム

2）＊はライシメーター試験における結果（以下，同様) 
表 3 荒茶の化学成分

(乾物当たり\%)

\begin{tabular}{|c|c|c|c|c|c|c|c|c|c|}
\hline \multirow{2}{*}{ 成分名 } & \multirow{2}{*}{ 区名 } & \multicolumn{3}{|c|}{1 年目 } & \multicolumn{3}{|c|}{2 年目 } & \multicolumn{2}{|c|}{3 年目 } \\
\hline & & 一番茶 & 三番茶 & 三番茶 & 一番茶 & 二番茶 & 拝茶 & 一番茶 & 二番茶* \\
\hline 全窒素 & 対照区 & 6.2 & 4.2 & 4.2 & 6.1 & 4.9 & 4.9 & 6.7 & 4.3 \\
\hline & $\mathrm{Dd}$ 区 & 6.1 & 4.4 & 4.3 & 6.3 & 5.0 & 4.8 & 6.9 & 4.5 \\
\hline 遊離アミノ酸 & 対照区 & 4.4 & 1.9 & 1.6 & 4.1 & 2.1 & 1.3 & 4.4 & 1.0 \\
\hline & Dd区 & 4.3 & 2.2 & 1.7 & 4.3 & 2.3 & 1.3 & 4.7 & 1.3 \\
\hline NDF & 対照区 & 17.5 & 25.8 & 25.0 & 18.8 & 22.0 & 20.7 & 16.2 & 22.8 \\
\hline & Dd区 & 17.6 & 24.6 & 25.1 & 18.3 & 22.0 & 21.5 & 16.0 & 22.9 \\
\hline
\end{tabular}

表 4 各茶期における収穫茶葉の窒素含量

\begin{tabular}{|c|c|c|c|c|c|c|c|c|}
\hline \multirow{2}{*}{ 区名 } & \multicolumn{3}{|c|}{1 年目 } & \multicolumn{3}{|c|}{2 年目 } & \multicolumn{2}{|c|}{3 年目 } \\
\hline & 一番茶 & 二番茶 & 三番茶 & 一番茶 & 二番茶 & 言番茶 & 一番茶 & 二番茶* \\
\hline 対照区 & 3.2 & 4.5 & 2.8 & 7.0 & 5.1 & 2.7 & 4.7 & 4.3 \\
\hline Dd区 & 3.0 & 4.7 & 3.2 & 7.7 & 5.7 & 2.9 & 5.0 & 4.4 \\
\hline
\end{tabular}

注）表 3 の全窒素含有率を用いて，生葉水分を全て $20 \%$ として算出した。

表 4 に各茶期にお沙収穫茶葉の空素含量 を示す。Dd区の窒素含量は，対照区に比べ て，1年目の一番茶を除き各茶期で多い傾向 にあった。

図 3 に 3 年目におけるう权間中央の細根量 を示す。Ddを 3 年間連用したDd区の細根量 は，0〜20cm及び20〜 40cmの層位で対照区 と同量であった。

図 4 にうね間土壤中の無機態緻素を示す。
Dd区の無機態窒素は，対照区に比べて， 2002 年 4 月の $0 \sim 20 \mathrm{~cm}$ 層位及び2003年 3 月 の20〜 40cm層位で少なかったが，その他の 時期では有意な差はなかった。一方，Dd区 の硝酸態窒素は，対照区に比べて，0〜 $20 \mathrm{~cm}$ 層位では，2002年 $4 \sim 6$ 月及び2003年 3 月で，20～40 cm層位では，2002年 $4 \sim 6$ 月及び2003年 $3 ， 6$ 月で少なかった。Dd区 のアンモニア態窒素は，0２0cm層位では，

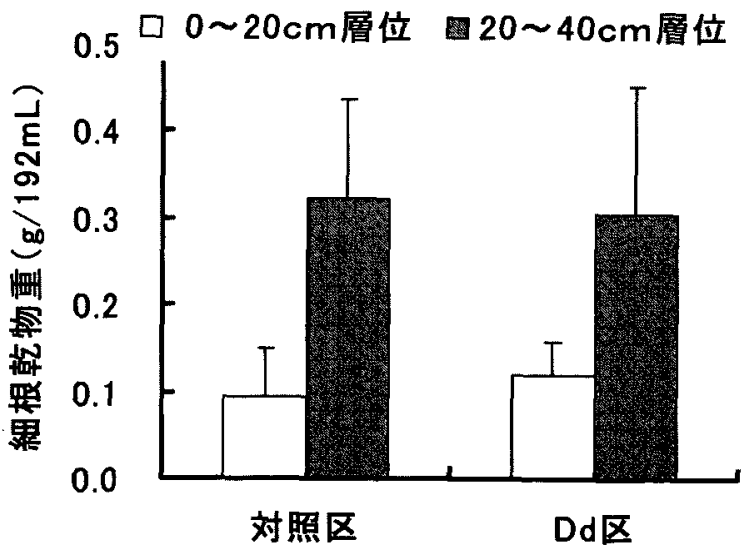

図 33 年目におけるうね間中央の細根量

注 1) 2004年 4 月 28 日採取, 直径 $35 \mathrm{~mm}$ の採土器

2）木化根は除く 
2002年 2 月で少なかったが，2003年 4 月で多

く, 20〜 40cm層位では, 2002年 3 月及び 6

〜 月，2003年 $3 ， 7$ 月で多かった。

\section{3 Dd入り被覆尿素の窒素溶脱への影響}

図 5 にライシメーターに扮ける月別土壤浸
透水量及び硝酸態窒素濃度を示す。両区の土 壌浸透水量は大差なかった。年間降水量（前 年 9 月〜当年 8 月）は， $1 ， 4$ 年目でそれぞ れ2,648，2,569mmと場内の平年值（30年平 均）と同等であったが，2，3 年目ではそれ ぞれ2,273，1,925mmと少雨傾向であった。
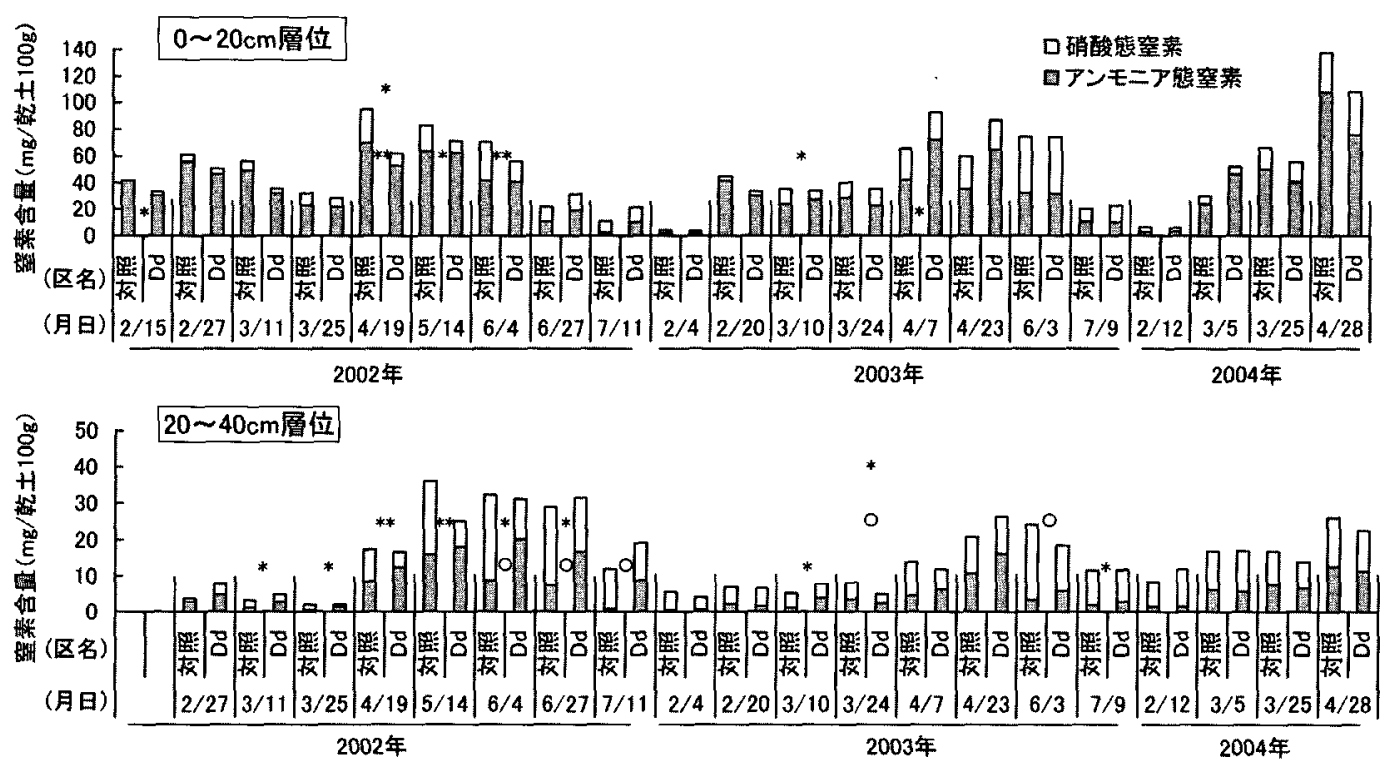

图 4 う杍間土墥中の無機態窒素

注）上段の印は無機態窒素，中段の印は硝酸態窒素，下段の印はアンモニア態窒素について，t検定 により，**は $<<0.01 ， *$ は $<0.05 ， \bigcirc は \mathrm{p}<0.1$ で有意差があることを示す。

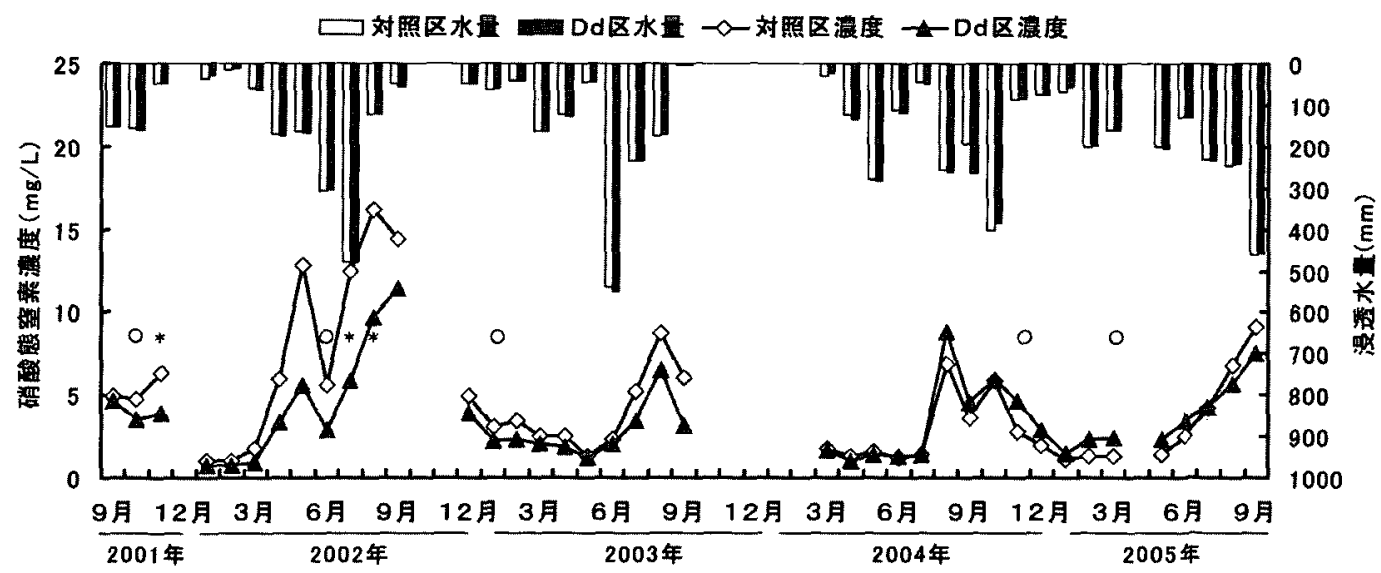

図 5 月別土壤漫透水量及び硝酸態窒妻濃度

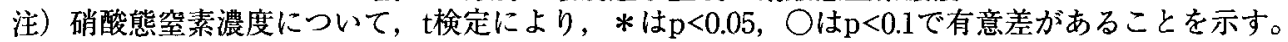


$\operatorname{Dd}$ 区の浸透水中の硝酸態窒素濃度は, 対 照区に比べて，2001年10～11月及び2002年 6 ～8月，2003年 1 月で低く，特に，2002年 7, 8 月の濃度差は，それぞれ $6.6,4.0 \mathrm{mg} / \mathrm{L}$ と非 常に大きかった。しかし，2004年11月及び 2005年 3 月では，濃度差は小さいものの，逆 にDd区の濃度が高くなった。

また，表 5 にライシメーター 4 年目におけ るうね間土壤の化学性を示す。 4 年経過後の Dd区のうね間土壌は, 対照区に比べて，全 窒素に有意な差はなかったが，可給態窒素は 多かった。

3.4 Dd入り被覆尿素の連用土壌におけ るアンモニア酸化細菌のDd感受性

図 6 に 4 年目におけるうね間土壤中のアン
モニア酸化細菌数を示す。 4 年経過後のアン モニア酸化細菌数は雨区の土壤でほほ同等で あった。しかし，その希釈液にDdを添加す ると，対照区ではアンモニア酸化細菌が減少 したが, Dd区では減少しなかった。

\section{4 考察}

茶園におけるDd入り被稪尿素の施用効果 を，窒素施用量を同量の $50 \mathrm{~kg} / 10 \mathrm{a}$ とした被 覆尿素との比較により検討した。

まず，各施肥時期におけるDd入り被覆尿 素の窒素溶出特性を調べたところ，8～9月 の秋肥時期施用ではリニア型， $4 \sim 5$ 月の夏 肥時期施用ではシグモイド型， 2 月の春肥時 期施用ではスーパーシグモイド型に近似して おり，他の被覆尿素と同様で温度依存性が高

表 54 年目におけるうね間土壤の化学性

（乾土当たり）

\begin{tabular}{|c|c|c|c|c|c|}
\hline \multirow{3}{*}{ 区名 } & \multirow{3}{*}{$\begin{array}{c}\mathrm{pH} \\
\left(\mathrm{H}_{2} \mathrm{O}\right)\end{array}$} & \multirow{3}{*}{$\begin{array}{l}\text { 全窒素 } \\
\mathrm{g} / 100 \mathrm{~g}\end{array}$} & \multirow{3}{*}{$\begin{array}{c}\text { 可給態 } \\
\text { 䓨蓄 } \\
\mathrm{mg} / 100 \mathrm{~g}\end{array}$} & \multicolumn{2}{|c|}{ 無機態窒素 } \\
\hline & & & & $\mathrm{NH}_{4}-\mathrm{N}$ & $\mathrm{NO}_{3}-\mathrm{N}$ \\
\hline & & & & \multicolumn{2}{|c|}{$\mathrm{mg} / 100 \mathrm{~g}$} \\
\hline 対照区 & 3.53 & 0.94 & 11.5 & 12.8 & 14.6 \\
\hline Dd区 & 3.63 & 1.03 & $19.3^{*}$ & 9.7 & 14.0 \\
\hline
\end{tabular}

注 1） 0 20cm層位，2005年 8月15日採土

2） $t$ 検定により，＊は $\mathrm{p}<0.05$ で有意差があることを示す。

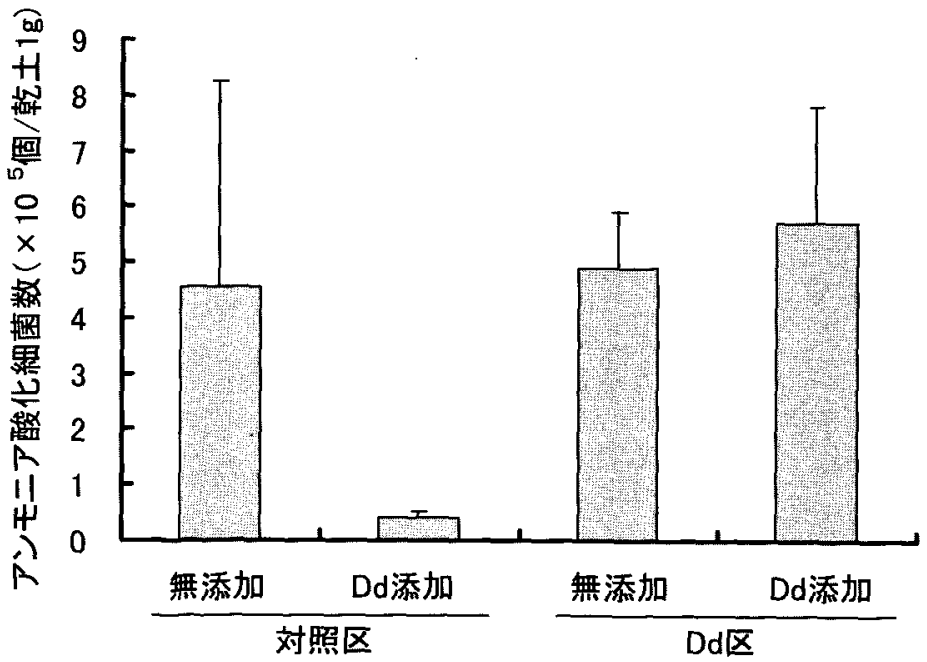

图64 年目におけるうね間土埕中のアンモニア酸化細菌

注） $0 \sim 20 \mathrm{~cm}$ 層位，2005年 9 月 26 日採土 
かった ${ }^{9)}$ 。しかし，Dd入り被覆尿素40及び 70日タイプの窒素溶出はいずれも被覆尿素に 比べて初期溶出が遅く，特にDd入り被覆尿 素70日タイプでは, 春肥時期の溶出が著しく 遅かった。同40日タイプでも春肥時期の初期 溶出が趛かったが，被覆尿素70日タイプと同 程度であった。その原因として，尿素にDd と被膜を二重にコーティングしているDd入 り被覆尿素の構造上の理由が考えられた。 れらのことから，Dd入りの効果を被覆尿素 70日タイプと比較するためには，特に春肥施 用ではDd入り被覆尿素70日タイプより同40 日タイプが望ましいと考えられた。

次に, 秋肥及び春肥, 夏肥にDd入り被覆 尿素をうね間に施用して茶の収量及び品質, うね間土壤への影響を検討した。Dd区の生 葉収量は 3 年間の各茶期通じて, 対照区と差 はなかったが, 荒茶の全窒素及び遊離アミノ 酸含有率が 2 年目の三番茶を除いて高く, 二, 三番茶の香気・水色・滋味で優れた。更に, 收穫茶葉の窒素含量が 1 年目の一番茶以降增 加傾向にあったことから，Dd入り被覆尿素 の施用による窒素吸収量の増加が, 二, 三番 茶の品質向上に寄与したと考えられた。この ことは，5月にDd添加肥料を用いると，二 番茶の空素含有率や品質が向上した西野 ${ }^{5}$ の結果と類似していた。また， 3 年目におけ るうね間の細根量は両区とも差はなく, Dd がチャの根の生育に影響を及ぼすことはない と考えられた。一方，うね間土壤中における Dd区の無機態室素は， 1 年目の 4 月の 0 一 $20 \mathrm{~cm}$ 層位で少なかったが, これは春肥に溶 出の遲いDd入り被覆尿素70日タイプを施用 したためと考えられた。しかし，Dd区の硝 酸態窒素は $1 ， 2$ 年目の $3 \sim 6$ 月の各層位で 少なく, Dd区のアンモニア態窗素は， 2 年 目の 4 月の $0 \sim 20 \mathrm{~cm}$ 層位, 1,2 年目の 3 〜 月の $20 \sim 40 \mathrm{~cm}$ 層位で多く推移したこと は, Ddによる硝化抑制効果によるものと考 えられた。石垣 ${ }^{10)}$ は, チャは野菜類と異な
り，土壤中の硝酸よりもアンモニアを優先的 に吸収する好アンモニア性作物であり，培盖 液中の無機態窒素に占めるアンモニア態窒素 比率が高い場合, 一番茶の絰素及びアミノ酸 含有率が高くなることを報告している。従っ て，本研究に抄ける硝化抑制によるう权間土 壌中のアンモニア態窒菜比率の向上は，荒茶 の全窒素及びアミノ酸含有率を高めて, 荒茶 品質の向上に寄与したと考えられた。

次に, 窒素溶脱への影響について, ライシ メーターで検討した。Dd区の浸透水中の硝 酸態窒素濃度は, 対照区に比べて， $1 ， 2$ 年 目は低く推移し, 特に 1 年目の 2002 年 $7 \sim 8$ 月に顕著な差が認められた。このことは， Ddの施用により硝酸態窒素の生成が抑えら れたためと考えられた。

一方，図 5，6で示すように，2004年のう 間土壤中のアンモニア態窒素比率は雨区差 がなく，2004年11月や2005年 3 月の溶脱空素 濃度はDd区で逆に高くなった。うね間の跡 地土壤を分析した結果, 可給態窒素がDd区 で対照区より多かったことから，Ddの施用 により，1〜2年目に溶脱が抑えられたう极 間土壤中のアンモニア態呿素が, 有機化して 蓄皘し， $3 \sim 4$ 年目に溶脱した可能性が考え られた。また，うね間土壤のアンモニア酸化 細菌を調べたところ，Ddの添加により対照 区ではアンモニア酸化細菌数が減少したが, Dd区では減少しなかった。このことは，Dd 入り被覆尿素の連用によりアンモニア酸化細 菌のDdに対する感受性が低下したことや， Ddに耐性のある硝化菌が優性になったこと， Ddを分解する微生物が増加したこと等の可 能性が推測された。

以上の結果から, 秋肥及び春肥, 夏肥で Dd入り被覆尿素を利用すると，Ddの硝化抑 制作用により，被覆尿素を利用した場合に比 べて窒素溶脱が低減し，施肥空素の吸収率が 高まることで，二，三番茶の品質が向上する ことが明らかとなった。しかし，Ddを年間 
を通じて連用することにより，可給態窒素の 増加に伴う窒素溶脱の增加や, Ddの施用過 剩による硝化抑制効果の低下の可能性が認め られたことから, 効果の持続性を高める施用 方法を検討する必要があると思われた。

\section{5 摘 要}

茶園土裹に抢ける長期間の硝化抑制効果を 目的として, 硝化抑制剤Ddと尿素を被覆し たDd入り被覆尿素の施用技術を検討した。 Dd入り被覆尿素70日タイプの溶出は, 被覆 尿素70日タイプより, 特に低温時期で溶出が 藷しく遅かった。被覆沓素70日タイプと同じ 溶出特性を得るためには，春肥ではDd入り 被覆尿素40日タイプの施用が望ましいと考え られた。また，秋肥及び夏肥，春肥でDd入 り被覆尿素を利用すると, Ddの硝化抑制作 用により,被覆尿素よりも窑素溶脱が低隇し, 施肥窒素の吸収率が高まることで, 二, 三番 茶の品質が向上した。しかし，Dd入り被覆 尿素を年間を通じて連用すると，3〜4年目 はうね間土壤中に蓄積した窒素の分解や，ア ンモニア酸化細菌による硝化の抑制が低下す ることにより, 溶脱窒素濃度が低下しない可 能性が認められた。

\section{6 謝辞}

本研究の実施にあたってご協力いただいた JA鹿児島県経済連肥料農薬課, チッソ旭肥 料株式会社, 鹿児島県茶業試験場の関係各位, アンモニア酸化細菌についてご助言いただい た山口大学農学部の横山和平教授には, 深く 感謝申し上げます。

\section{7 引用文献}

1 ）㴊之上康元・㨽之上弘子（1999）：日本茶 全書, 農文協, 東京, pp.41, 82-87.

2 ）早津雅仁·松本幸典·三宅浩史・徳田進 一.中島田誠 (1992)：茶園土壌の硝酸化 成抑制法(1) 一各種硝化抑制剂の效果.
茶研報, No.76 (別)，60-61.

3 ）西野恒夫(1993)：茶園土誉における硝酸 化成抑制肥料及び硝酸化成抑制の効果 (第 1 報)。茶研報, №.78（別），52-53.

4) 野中一弥·中島田誠 (2005)：強酸性土壤 における硝酸化成抑制剂の効果. 茶研報, №.100, 76-77.

5 ）西野恒夫(1999)：茶の収量・品質に及ほ す施肥の影響と窒素溶脱軽減対策. 高知 県農業技術センター研究報告, № 8，8393.

6）加藤忠司・山口泰明・溝口健作 (1996)： 石灰窒素及びジシアンジアミド施用茶園 における無機態窒素の動態．茶研報，No. 84 (別), 134-135.

7 ）越野正義編著 (1988)：詳解肥料分析法 (第二改訂), 養賢堂, 東京, pp.27-31.

8 ）土壌環境分析法編集委員会編 (1997)：土 壤環境分析法, 博友社, 東京, pp.160-262.

9）伊達 昇・塩崎尚郎編著 (1997)：肥料便 覧第 5 版，農文協，東京，pp.90-107。

10）石垣幸三 (1978)：茶樹の栄養特性に関す る研究. 茶業試験場研究報告, No14, 1152. 